\title{
Patients, Doctors, and Legislators
}

\author{
Lisa H. Harris, $M D, P h D$
}

A s I prepared to examine a new patient, "B," I commented on her lovely necklace. B told me that her mother had given it to her more than 20 years ago, when she was diagnosed with a serious medical condition. "Oh?" I asked. My curiosity was piqued-B hadn't reported any important family history. Her mother, it turned out, had Huntington's disease. The necklace was a gift, given before her mother died and before Huntington's wreaked its significant cognitive and physical havoc. I probed a little further: "What have you decided to do about genetic testing for yourself?" "I was tested," B told me. There was no drama or sadness in her voice, so I was prepared for her to tell me that she tested negative. She calmly offered, "I am positive for the Huntington's gene." I felt the blood drain from my head but kept my composure. Then B added-gesturing to her lower abdomen-"that is why I am here today."

I completed her abortion procedure quickly and uneventfully. As I finished my charting, I thought about what that most simple statement, "that is why I am here today," might have meant: That it was excruciating to watch her mother die from a debilitating neurologic illness and she did not want her own child to go through the same thing? Or that she knew if she continued her pregnancy, she might not live to raise her child beyond adolescence? Or that she needed to focus the next years on keeping herself healthy, not on pregnancy and raising a child? Or that there was

From the Division of Gynecology and Program in Sexual Rights and Reproductive Justice, Department of Obstetrics and Gynecology, the Department of Women's Studies, and the Center for Bioethics and Social Sciences in Medicine, University of Michigan, Ann Arbor, Michigan.

The author thanks "B," the patient discussed in this article, for granting permission to share her story.

Corresponding author: Lisa H. Harris, MD, PhD, Department of Obstetrics and Gynecology, University of Michigan, L4000 Women's Hospital, 1500 East Medical Center Drive, Ann Arbor, MI 48109; e-mail: Ihharris@med.umich.edu.

Financial Disclosure

The author did not report any potential conflicts of interest.

(C) 2012 by The American College of Obstetricians and Gynecologists. Published by Lippincott Williams \& Wilkins.

ISSN: 0029-7844/12 a 50-50 chance she already had passed the gene on to the 10-week fetus she had been carrying and a familial thread of illness and loss would go on and on? In nearly 20 years as a physician-many of those years as an abortion provider-I had not seen or imagined this particular scenario before: the sad combination of medical and social details that resulted in B sitting on my examination table that day.

And I was struck, as I am nearly every day that I see patients, that no two days are ever exactly alike; there is always something new. No two overnight shifts on Labor and Delivery or days in the office, births or cesarean deliveries or cases of preeclampsia or miscarriages or abortions...are ever exactly the same, because no two patients are ever exactly alike. There is inevitably some point in most days where I am caught a little off guard, and humbled, because, while I have a great deal of medical knowledge and experience, I don't have experience with exactly this situation. Every patient brings her own body, medical history, unique manifestation of even mundane ailments, and set of potential or actual complications, not to mention social contexts, worries, and hopes and meanings. Thus, every day is a little different from every other day, and practicing medicine is rarely boring. Sometimes the new element is a technical challenge, and sometimes it is social one-but I can always count on something to be new.

The doctors I most admired in my training were those who let themselves be humbled and perplexed by the varied presentations of their patients, doctors who did not assume they had seen exactly this case before, who even relished the uncertainty that a new patient brought. These doctors really listened, looked, questioned, pondered, and "put their thinking caps on," as my first grade teacher would have described. And when they were at the limit of their certainty, they did not hesitate to say to a patient "I have not seen this situation before, and I am not exactly sure what the best thing for you is at this moment." Then they would ask for help-maybe through a consult or a literature search, or perhaps just by soliciting the two 
cents of a trusted colleague. I also observed that not all doctors were comfortable with uncertainty and humility, which struck me (and still does) as a little dangerous. On a number of occasions, I observed as doctors made assumptions that one case was just like another they'd seen, leading to missed historical details, wrong diagnoses, complications, and, at the very least, failed opportunities to connect with a patient. I try to be the kind of doctor who recognizes and relishes the uniqueness of every patient's physiologic and psychosocial presentation and who recognizes the limits of my knowledge and skills.

To be reminded on that particular day that patients always bring new sets of circumstances to their medical encounters was especially moving-and infuriatingbecause that day my state's House Committee on Health Policy was voting on a set of new bills (HB5711 ${ }^{1}, \mathrm{HB} 5712^{2}$, and HB5713 ${ }^{3}$ ) that would, as they were designed to, significantly restrict abortion services for all women in Michigan. ${ }^{1-3}$ The omnibus package included a variety of "supply" side restrictions-restrictions aimed at making it impossible for doctors to offer abortion care. These include malpractice insurance coverage requirements that would be difficult, if not impossible, for abortion providers to meet; requirements that abortion (including medication abortion) be provided only in facilities designated as free-standing surgical centers; fetal-remains disposition requirements that would be burdensome for providers (as well as patients); and a ban on abortion after 20 weeks, with no exception for a woman's health, fetal anomaly, rape, or incest. I leave it to advocates and activists to analyze the specific implications of these bills. The relevant question for me-writing as a physician who recognizes that every single day presents situations I have not seen before-is: Did legislators have my particular patient in mind as they cast committee votes in favor of the bills? Did they indeed know exactly what was best for B that day? And do they know what is best for the many other patients I will see in the days and weeks ahead? To be clear, I am not making the case that there are worthy and unworthy abortions and that B was worthy of abortion care because of her particular circumstances. I am saying quite the opposite: every person's body, every symptom, every set of circumstances and health needs is different. Unique combinations and permutations lead women to my office examination table, where they explain, if they want to, "that is why I am here today." Good doctors are prepared daily to listen, look, think, and to be challenged, surprised, stumped, and, most importantly, to be humbled-to recognize that, for all of their experience, something will be new that day and they may not know the right answer. Are these not the characteristics of good legislators, too?

\section{REFERENCES}

1. Michigan House Bill No 5711. Available at: http://legislature. mi.gov/doc.aspx?2012-HB-5711. Retrieved August 8, 2012.

2. Michigan House Bill No 5712. Available at: http://legislature. mi.gov/doc.aspx?2012-HB-5712. Retrieved August 8, 2012.

3. Michigan House Bill No 5713. Available at: http://legislature. mi.gov/doc.aspx?2012-HB-5713. Retrieved August 8, 2012. 